\title{
Dampak Pandemi COVID-19 terhadap Kinerja Nilai Ekspor Pertanian Indonesia
}

\author{
Achmad Subchiandi Maulana ${ }^{a}$, Agustinus Nubatonis ${ }^{\mathrm{b}}$ \\ ${ }^{a}$ Fakultas Pertanian, Universitas Timor, Kefamenanu,TTU - NTT, Indonesia.Email : achmadsm@ unimor.ac.id \\ ${ }^{b}$ Fakultas Pertanian, Universitas Timor, Kefamenanu, TTU - NTT, Indonesia.email : agustinusnubatonis74@ gmail.com
}

\section{Article Info}

\section{Article history:}

Received 20 Agustus 2020

Received in revised form 13 September 2020 Accepted 8 Oktober 2020

$\mathrm{DO}$

https://doi.org/10.32938/ag.v5i4.1166

\section{Keywords:}

COVID-19

Ekspor

Nilai Ekspor Pertanian

\section{Abstrak}

Pandemi coronavirus menyebabkan dunia masuk dalam kondisi krisis baik krisis kesehatan maupun krisis ekonomi. Akibat dari virus in perdagangan antar negara menjadi terhambat, sebab terjadi lockdown (pembatasan sosial berskala besar) yang mengakibatkan pertumbuhan ekonomi berjalan lambat. Ekspor merupakan salah satu kegiatan perdagangan internasional yang dilakukan oleh Indonesia. Sektor pertanian menyumbang 2,3\% dari total ekspor Indonesia, namun sektor pertanian merupakan sektor yang mampu bertahan dalam keadaan krisis. Melihat keadaan tahun 2020 yang sedang terjadi pandemik Covid-19 dalam beberapa bulan terakhir, menarik untuk dicermati apakah krisis global yang disebabkan oleh Covid-19 membuat perubahan signifian dalam kinerja nilai ekspor hasil pertanian Indonesia. Data yang digunakan adalah data bulanan dianalisis menggunakan regresi linier berganda, dengan variabel dependen adalah nilai ekspor pertanian Indonesia, sedangkan variabel independennya adalah pendapatan domestik bruto nasional, kurs nilai tukar rupiah terhadap dolar Amerika Serikat, volume ekspor Indonesia, volume ekspor pertanian Indonesia, dan COVID-19 sebagai variabel dummy. Hasilnya adalah, variabel yang berpengaruh nyata terhadap nilai ekspor pertanian Indonesia adalah volume ekspor Ind onesia dan volume ekspor pertanian Indonesia, sedangkan variabel lainnya tidak berpengaruh sacara signifikan.

\section{Pendahuluan}

Coronavirus adalah suatu kelompok virus yang dapat menyebabkan penyakit pada hewan atau manusia. Beberapa jenis coronavirus diketahui menyebabkan infeksi saluran nafas pada manusia mulai dari batuk pilek hingga yang lebih serius seperti Middle East Respiratory Syndrome (MERS) dan Severe Acute Respiratory Syndrome (SARS). Coronavirus jenis baru yang ditemukan menyebabkan penyakit Covid-19, sedangkan Covid-19 adalah penyakit menular yang disebabkan oleh jenis coronavirus yang baru ditemukan. Virus baru dan penyakit yang disebabkannya ini tidak dikenal sebelum mulainya wabah di Wuhan, Tiongkok, bulan Desember 2019. Covid 19 ini sekarang menjadi sebuah pandemi yang terjadi di banyak negara di seluruh dunia (WHO, 2020).

Pandemi coronavirus menyebabkan dunia masuk dalam kondisi krisis baik krisis kesehatan maupun krisis ekonomi. Akibat dari virus ini perdagangan antar negara menjadi terhambat, sebab terjadi lockdown (pembatasan sosial berskala besar) yang mengakibatkan pertumbuhan ekonomi berjalan lambat.

Perdagangan merupakan salah satu aktifitas ekonomi yang dilakukan hampir oleh seluruh orang di dunia ini pada skala tertentu mulai dari skala mikro yaitu perdagangan antar orang perorang atau perusahaan ke orang, dan perdagangan dengan skala makro biasanya dilakukan oleh suatu perusahaan dengan negara lain atau negara dengan negara, yang lebih dikenal dengan istilah ekspor dan impor.

Ekspor merupakan salah satu kegiatan perdagangan internasional yang dilakukan oleh Indonesia, sektor penting ekspor Indonesia dibagi menjadi dua jenis yaitu ekspor migas dan non migas. Ekspor non migas terdiri dari sektor pertanian, perkebunan, kehutanan, jasa, dan industri kerajinan.

Sektor pertanian menyumbang 2,3\% dari total ekspor Indonesia, diikuti oleh sektor migas sebesar $15,97 \%$, dan industri pengolahan sebesar $81,71 \%$ (BPS, 2020). Walaupun menyumbang nilai ekspor yang kecil namun sektor pertanian merupakan sektor yang mampu bertahan dalam keadaan krisis Menurut BAPPENAS (2009) sektor pertanian relatif kecil terkena dampak krisis ekonomi pada tahun 2008 dibandingkan dengan sektor lain. Dampak krisis kepada sektor pertanian lebih disebabkan dari sisi permintaan (demand side), dan bukan karena faktor keuangan finansial. Saat krisis ekonomi terjadi, sektor pertanian masih menjadi salah satu sektor yang diandalkan untuk penciptaan lapangan pekerjaan.

Data menunjukan bahwa ekspor hasil pertanian Indonesia terhadap dunia memiliki trend yang fluktuatif namun cenderung positif. Untuk melihat lebih jelas perkembangan ekspor Indonesia dapat diamati pada Tabel 1.

Tabel 1. Perkembangan Ekspor Hasil Pertanian Tahun 2012-2019

\begin{tabular}{cccc}
\hline Tahun & $\begin{array}{c}\text { Berat Bersih } \\
\text { (ribu ton) }\end{array}$ & $\begin{array}{c}\text { Nilai } \\
\text { (juta US\$) }\end{array}$ & $\begin{array}{c}\text { \% Perubahan } \\
\text { Nilai }\end{array}$ \\
\hline 2012 & 2268,4 & 3597,7 & 6,16 \\
2013 & 2462,2 & 3598,5 & 0,02 \\
2014 & 2777,3 & 3373,3 & $-6,26$ \\
2015 & 3621,5 & 3726,5 & 10,47 \\
2016 & 3453,0 & 3354,8 & $-9,98$ \\
2017 & 4177,6 & 3671,0 & 9,43 \\
2018 & 4345,4 & 3431,0 & $-6,54$ \\
2019 & 4981,7 & 3612,4 & 5,29 \\
\hline
\end{tabular}

Sumber : BPS 2020

Melihat keadaan tahun 2020 yang sedang terjadi pandemik Covid-19 dalam beberapa bulan terakhir, menarik untuk dicermati apakah krisis global yang disebabkan oleh Covid-19 membuat perubahan signifikan dalam kinerja nilai ekspor hasil pertanian Indonesia.

\section{Metode}

\subsection{Jenis dan Sumber Data}

Data yang digunakan untuk penelitian ini bersumber dari BPS dan menggunakan data sekunder ekspor sektor pertanian Indonesia bulanan yang di ambil dari bulan Mei 2018 sampai Juni 2020. Variabel penelitian ini adalah nilai ekspor pertanian untuk variable dependen, sedangkan variabel independennya adalah PDB Nasional, volume ekspor total, volume ekspor pertanian, dan nilai tukar, serta variabel dummy COVID-19.

\subsection{Metode Analisis Data}

Untuk mengetahui dampak COVID-19 terhadap kinerja ekspor pertanian Indonesia, maka data yang sudah diperoleh dianalisis dengan metode regresi linier berganda yang diubah menjadi persamaan logaritma natural. Perangkat lunak yang digunakan untuk menganalisis data dalam penelitian ini adalah $E$ views 9. Menurut Sugiyono (2016) analisis regresi linear berganda merupakan regresi yang memiliki satu variabel dependen dan dua atau lebih variabel independen. Persamaan regresi berganda untuk penelitian ini secara umum dapat dirumuskan sebagai berikut:

$$
\begin{aligned}
& \ln \operatorname{EXPP}_{\text {it }}=a+b_{1}\left(\operatorname{lnPDBN}_{\text {it }}\right)+b_{2}\left(\operatorname{lnVEXP}_{\text {it }}\right)+b_{3}\left(\operatorname{lnVEXPP}_{\text {it }}\right)+b_{4}\left(\operatorname{lnEXCRT} T_{\text {it }}\right) \\
& +b_{5} \text { COVID }-19+E_{i t} \\
& \text { = Error term }
\end{aligned}
$$

\subsection{Uji F-statistic}

Uji F-statistic dilakukan untuk mengetahui pengaruh variabel independen atau independen secara bersama-sama terhadap variabel dependen atau dependen.

\subsection{Uji t-statistic}

Uji t pada dasarnya menunjukkan seberapa jauh pengaruh satu variabel independen secara individual dalam menerangkan variasi variabel dependen. Tujuan dari uji t adalah untuk menguji koefisien regresi secara individual.

\section{5. $\quad$ R-Squared $\left(\mathbf{R}^{2}\right)$}

Kesesuaian model dihitung dengan nilai koefisien determinasi (R2) yang bertujuan untuk mengukur keragaman variabel independen yang dapat diterangkan oleh variabel dependen. $\mathrm{R}^{2}$ menunjukkan besarnya pengaruh semua variabel independen terhadap variabel dependen.

\subsection{Pengujian Asumsi Model}

Dalam permasalahan analisis regresi berganda sering ditemukan masalah yang perlu dilakukan pengujian asumsi klasik, antara lain pengujian normalitas, multikolinearitas, autokorelasi, dan heteroskedastisitas.

\section{a. Normalitas}

Uji normalitas bertujuan untuk menguji apakah dalam model regresi, variabel pengganggu atau residual memiliki distribusi normal. Seperti diketahui bahwa uji t dan $\mathrm{f}$ mengasumsikan bahwa nilai residual mengikuti distribusi 
normal. Persamaan regresi dikatakan baik jika mempunyai variabel bebas dan variabel terikat berdistribusi normal (Ghozali, 2011).

Ada beberapa uji untuk mengetahui normal atau tidaknya nilai residual antara lain dengan menggunakan Jarque-Bera test atau J-B test. Uji ini menggunakan hasil estiminasi residual dan chisquare probability distribution (Gujarati, 2006). Bila nilai J-B hitung $>$ nilai $\mathrm{X}^{2}$ tabel atau Prob $<0.05$, maka hipotesis yang menyatakan bahwa residual berdistribusi normal dapat ditolak. Bila nilai J-B hitung < nilai $\mathrm{X}^{2}$ tabel, atau Prob > 0,05 maka yang menyatakan bahwa residual berditribusi normal tidak dapat ditolak.

\section{b. Multikolinearitas}

Menurut Ghozali (2011) uji multikolinearitas bertujuan untuk menguji apakah model regresi ditemukan adanya korelasi antar variabel independent (bebas). Alat uji yang digunakan untuk mengetahui multikolinearitas dalam penelitian ini dengan menggunakan Variance Inflation Factor (VIF) dan Tolerance. Model regresi yang terbebas dari multikolinearitas adalah yang memiliki nilai tolerance mendekati 1 dan nilai VIF kurang dari 10.

\section{c. Heteroskedastisitas}

Menurut Ghozali (2011), Uji heteroskedastisitas merupakan alat uji model regresi untuk mengetahui ketidaksamaan variance dari residual satu pengamatan ke pengamatan yang lainnya. Jika variance dari residual satu pengamatan ke pengamatan lain tetap, maka disebut homoskedastisitas dan jika berbeda disebut heteroskedastisitas. Model regresi yang baik adalah yang homoskedastisitas atau tidak terjadi masalah heteroskedastisitas. Penelitian ini menggunakan parameter uji Breusch-Pagan-Godfrey untuk mengetahui apakah terjadi heteroskedastisitas dalam model regresi yang diperoleh.

\section{d. Autokorelasi}

Autokorelasi sering terjadi pada pengamatan yang dilakukan pada data runtun waktu (time series). Autokorelasi adalah keadaan di mana terdapat trend di dalam variabel yang diteliti, sehingga akibatnya $\varepsilon$ juga mengandung trend. Autokorelasi terjadi jika antara $\varepsilon$ t dan $\varepsilon t-1$ terdapat korelasi yang tinggi, jika terdapat autokorelasi, maka parameter b yang diperoleh tetap linier dan tidak bias, tetapi Sb bias akibatnya uji signifikansi variabel yang dilakukan dengan uji-t tidak bisa dilakukan. Pendeteksian terhadap adanya autokorelasi dilakukan dengan menggunakan uji Durbin Watson Test (Gujarati, 2006).

\section{Hasil dan Pembahasan}

\subsection{Analisis Dampak Pandemi COVID-19 Terhadap Kinerja Ekspor} Pertanian Indonesia

Faktor-faktor yang diduga berpengaruh terhadap nilai ekspor pertanian Indonesia pada saat terjadi pandemi COVID-19 antara lain adalah pendapatan domestik bruto nasional (PDBN), nilai tukar rupiah terhadap dolar Amerika Serikat (EXCRT), volume ekspor Indonesia (VEXP), volume ekspor pertanian Indonesia (VEXPP), dan Covid-19 (COVID). Pada saat melakukan regresi variabel-variabel tersebut diubah terlebih dahulu menjadi bilangan logaritma natural (LN) karena terdapat perbedaan angka yang besar antara variabel yang menyebabkan data tidak bersifat homogen. Hasil estimasi model yang sudah dianalisis menggunaka perangkat lunak E-views 9 dapat dilihat pada tabel dibawah ini

Tabel 2. Hasil estimasi model regresi linier berganda dampak corona virus terhadap nilai ekspor pertanian Indonesia

\begin{tabular}{lccc}
\hline Variabel & Koefisien & $\begin{array}{c}\text { Probabilitas } \\
\text { (t-statistic) }\end{array}$ & $\begin{array}{c}\text { Centered } \\
\text { VIF }\end{array}$ \\
\hline C & -15.3078 & 0.1021 & NA \\
LNPDBN & 0.002814 & 0.9542 & 1.606479 \\
LNEXCRT & 0.733594 & 0.2227 & 1.172025 \\
LNVEXP & 0.686481 & 0.0347 & 2.110065 \\
LNVEXPP & 0.542190 & 0.0005 & 1.762540 \\
COVID-19 & -0.01687 & 0.7594 & 1.866741 \\
R-squared & 0.724776 & & \\
Durbin-Watson stat & 1.819877 & & \\
Prob(F-statistic) & 0.000046 & & \\
Prob (Jarque-Bera) & 0.645828 & & \\
Prob. Chi-Square $(5)$ & 0.8226 & & \\
Keterangan $\alpha=5 \%(0,05)$ & & &
\end{tabular}

\subsection{Uji Kriteria Statistik}

Uji kriteria statistik dilakukan untuk mengetahui apakah variabel independen yang digunakan dalam penelitian berpengaruh secara nyata atau sebaliknya terhadap variabel dependennya. Uji yang dilakukan adalah uji $\mathrm{F}$ dan uji-t. Uji F digunakan untuk mengetahui pengaruh variabel independen secara keseluruhan terhadap variabel dependennya. Terlihat dalam tabel 2, bahwa nilai probabilitas untuk uji $\mathrm{F}$ sebesar 0,000046 yang lebih kecil dari taraf nyata sebesar $5 \%$, sehingga dapat disimpulkan bahwa secara bersama-sama variabel independent berpengaruh terhadap variabel dependennya.

Uji-t menjelaskan secara individu dari variabel independent apakah berpengaruh secara signifikan terhadap variabel dependen. Pada tabel 2 dapat dilihat bahwa hanya ada 2 variabel yang signifikan pada taraf nyata $5 \%$, yaitu variabel volume eskpor Indonesia (VEXP) dan volume ekspor pertanian Indonesia (VEXPP).

Nilai $R^{2}$ pada tabel 2 menunjukkan angka sebesar 0,724776 yang artinya adalah model regresi diatas mampu menjelaskan tentang dampak COVID-19 terhadap nilai ekspor pertanian Indonesia sebesar 72,5\%, sisanya sebesar 27,5\% dijelaskan oleh variabel lain diluar variabel yang dianalisis.

\subsubsection{Uji Normalitas}

Uji normalitas dilakukan dengan melihat nilai probabilitas yang terdapat pada histogram-normality test. Apabila nilai probabilitas Jarque-Bera lebih besar dari taraf nyata 5\% maka artinya error term menyebar normal (Ghozali, 2011). Dari hasil uji normalitas pada tabel 2 diatas nilai probabilitasnya $0,645828>0,05$ artinya error term dalam persamaan Dampak Covid-19 terhadap kinerja ekspor peranian Indonesia telah menyebar normal.

\subsubsection{Uji Multikolinieritas}

Hasil uji multikolinieritas menggunakan nilai centered VIF menunjukkan bahwa tidak ada korelasi atau interkorelasi antara variabel bebas yang di uji dalam model regresi, hal tersebut ditegaskan dengan tidak adanya nilai centered VIF yang tidak lebih dari 10.

\subsubsection{Uji Heteroskedastisitas}

Heteroskedastisitas di uji menggunakan Breusch Pagan Godfrey dengan menggunakan parameter probability chi square (5) dengan nilai sebesar 0,8226, nilai tersebut lebih besar dari nilai probabilitas 5\% $(0,05)$, sehingga disimpulkan bahwa model regresi bersifat homoskedastisitas.

\subsubsection{Uji Autokorelasi}

Hasil pengujian autokorelasi menggunakan Durbin Watson, diperoleh nilai hitung adalah 1,8198 dan untuk nilai 4-d adalah 2,1802, sedangkan nilai Durbin Watson Tabel untuk sampel sebanyak 26 dengan variabel bebas sebanyak 5 adalah $\mathrm{dU}=1,06158$ dan $\mathrm{dL}=1,75911$, hal ini menunjukkan bahwa tidak ada korelasi positif maupun negatif dari model regresi sebab nilai Durbin Watson hitung lebih besar dari nilai Durbin Watson tabel.

\subsection{Analisis Faktor-Faktor yang Mempengaruhi Nilai Ekspor Pertanian Indonesia}

Sektor pertanian merupakan salah satu penyumbang devisa bagi negara Indonesia yang mampu bertahan dalam keadaan krisis sekalipun. Menurut Yusdja (2011), krisis ekonomi global yang terjadi pada tahun 2008 tidak berpengaruh signifikan terhadap sektor pertanian, Hal tersebut terjadi karena komoditas pertanian merupakan kebutuhan dasar manusia untuk bertahan hidup, sehingga meskipun krisis terjadi, sektor pertanian akan mampu bertahan. Model regresi dari analisis yang dilakukan adalah sebagai berikut :

\section{LNEXPP $=-15.3078+0.002814 *$ LNPDBN $+0.733594 *$ LNEXCRT + $0.686481 *$ LNVEXP $\quad+\quad 0.542190 *$ LNVEXPP $0.016871 *$ COVID}

\section{a. Konstanta}

Persamaan di atas menunjukan bahwa nilai konstanta bernilai negatif 15,3078 artinya adalah apabila tidak ada pengaruh dari variabel lain maka nilai ekpor pertanian Indonesia menurun sebesar 15,3078\%.

\section{b. PDB Nasional}

Nilai dari variabel LNPDBN adalah positif 0,002814, hal ini menunjukkan bahwa apabila nilai PDB Nasional meningkat sebesar $1 \%$ akan meningkatkan nilai ekspor pertanian Indonesia sebesar 0,2814\%. Namun variabel ini tidak signifikan menurut uji t, tetapi apabila digabungkan dengan variabel lain maka PDB Nasional memiliki pengaruh, oleh karena itulah nilai uji F bernilai signifikan. Hal ini sejalan dengan penelitian Fikriah (2016) yang berjudul berjudul Analisis Pengaruh Produk Domestik Bruto, Nilai Tukar, dan Sosial Politik Terhadap Net Capital Inflow Indonesia, dimana PDB berpengaruh positif terhadap Net Capital Flow Indonesia, namun yang membedakan adalah secara uji t PDB dalam penelitian tersebut bersifat signifikan.

c. Kurs Nilai Tukar Rupiah Terhadap Dolar

Variabel LNEXCRT adalah variabel yang menjelaskan pengaruh kurs nilai tukar rupiah terhadap dolar Amerika Serikat. Persamaan diatas menunjukkan bahwa nilai variabelnya sebesar positif 0,733594 yang artinya apabila ada kenaikan nilai tukar sebesar $1 \%$, maka nilai ekspor pertanian Indonesia akan meningkat sebesar 0,733594\%, keadaan ini menunjukkan bahwa apabila nilai tukar rupiah terdepresiasi akan meningkatkan ekspor menjadi lebih besar lagi, hal ini dikemukakan oleh Maulana (2016). Namun variabel ini tidak berpengaruh signifikan berdasarkan uji t, tetapi secara bersama-sama melalui uji $\mathrm{F}$ variabel bersifat signifikan.

d. Volume Ekspor Indonesia

Nilai dari variabel LNVEXP adalah positif 0,686481 yang artinya adalah apabila volume ekspor Indonesia meningkat sebesar 1\% maka akan meningkatkan nilai ekspor pertanian sebesar $0,686481 \%$. Signifikansi untuk variabel ini adalah memiliki pengaruh berdasarkan nilai uji t yaitu dengan probabilitas $5 \%$ atau $0,0347<0,05$. Karena komoditas pertanian merupakan salah satu komoditas unggulan, maka otomatis apabila volume ekspor total Indonesia bertambah akan berpengaruh terhadap nilai ekspor pertanian. Penelitian Maisyarah (2019) yang berjudul Pengaruh Nilai Tukar, Volume Ekspor, Dan Bea Keluar Terhadap Harga Ekspor Pinang (Studi Kasus Pada Perusahaan Eksportir CV. Mulia Karya), menjelaskan bahwa volume ekspor berpengaruh positif terhadap harga ekspor pinang. Dalam penelitian tersebut 
variabel volume ekspor bersifat signifikan secara uji t, sedangkan dalam penelitian ini tidak signifikan.

e. Volume Ekspor Pertanian Indonesia

Variabel LNEXPP merupakan variabel yang menjelaskan tentang jumlah ekspor pertanian Indonesia, secara uji t variabel ini mempunyai nilai yang signifikan karena probabilitas thitung lebih kecil dari batas tingkat kepercayaan sebesar $5 \%$ yaitu $0,0005<0,05$. Hal ini menunjukkan bahwa setiap ada kenaikan volume ekspor pertanian sebesar $1 \%$ akan meningkatkan nilai ekspor pertanian sebesar $0.542190 \%$. Merujuk pada penelitian Lestari (2018) yang berjudul Factors Affecting Clove Exportsin North Sumatera Province, menjelaskan bahwa variabel jumlah ekspor tembakau berpengaruh positif terhadap ekspor tembakau Indonesia dan signifikan secara uji t, hal tersebut selaras dengan penelitian ini, dimana jumlah ekspor pertanian Indonesia memiliki pengaruh positif terhadap nilai ekspor dan signifikan secara uji t.

\section{f. Pandemi COVID-19}

COVID-19 merupakan variabel dummy yang menjelaskan dampak COVID-19 terhadap nilai ekspor pertanian Indonesia, nilai variabelnya adalah negatif 0,01687 , namun berdasarkan kriteria uji t variabel ini tidak signifikan karena nilai probabilitas hitungnya lebih besar dari nilai probabilitas yang ditentukan yaitu $0,7594>0,05$, tetapi apabila di uji Bersama-sama menggunkan uji $\mathrm{F}$ maka variabel ini bersifat signifikan. Arti nilai negatif 0,01687 adalah apabila ada pertambahan kasus COVID-19 pada bulan-bulan berikutnya, maka nilai ekspor pertanian Indonesia akan menurun sebesar 0,01687. Variabel dummy juga digunakan dalam penelitian Fikriah (2016) yang berjudul Analisis Pengaruh Produk Domestik Bruto, Nilai Tukar, dan Sosial Politik Terhadap Net Capital Inflow Indonesia, variabel dummy yang digunakan adalah Politik di Indonesia, hasilnya adalah variabel tersebut berpengaruh negatif terhadap $\mathrm{Net}$ Capital Inflow Indonesia dan secara statistik tidak signifikan.

Jika pandemi ini terus berlanjut dalam jangka panjang, besar kemungkin variabel ini menjadi signifikan secara uji t, solusi agar hal tersebut tidak terjadi adalah kepatuhan kita sebagai masayarakat tentang anjuran beraktifitas selama masa pandemi ini seperti memakai masker, menjaga jarak aman saat berinteraksi dengan orang lain, mencuci tangan sesering mungkin, hindari keramaian sebisa mungkin, berolahraga, dan mengkonsumsi minuman atau makanan yang mampu meningkatkan imun tubuh.

Tabel 3. Nilai Ekspor Pertanian Indonesia Perbulan

\begin{tabular}{|c|c|c|c|}
\hline Tahun & Bulan & $\begin{array}{l}\text { Nilai EXPP } \\
\text { (USD Juta) }\end{array}$ & Perubahan Perbulan (\%) \\
\hline \multirow[t]{8}{*}{2018} & Mei & 308300000 & 0 \\
\hline & Juni & 199700000 & -54.3816 \\
\hline & Juli & 299900000 & 33.41114 \\
\hline & Agustus & 302500000 & 0.859504 \\
\hline & September & 319200000 & 5.23183 \\
\hline & Oktober & 315900000 & -1.04463 \\
\hline & November & 319900000 & 1.250391 \\
\hline & Desember & 296600000 & -7.8557 \\
\hline \multirow[t]{12}{*}{2019} & Januari & 282400000 & -5.02833 \\
\hline & Februari & 233200000 & -21.0978 \\
\hline & Maret & 269300000 & 13.40512 \\
\hline & April & 252300000 & -6.73801 \\
\hline & Mei & 316300000 & 20.23396 \\
\hline & Juni & 209000000 & -51.3397 \\
\hline & Juli & 313900000 & 33.41829 \\
\hline & Agustus & 337800000 & 7.075192 \\
\hline & September & 356200000 & 5.165637 \\
\hline & Oktober & 339500000 & -4.919 \\
\hline & November & 334600000 & -1.46444 \\
\hline & Desember & 370100000 & 9.592002 \\
\hline \multirow[t]{6}{*}{2020} & Januari & 295900000 & -25.076 \\
\hline & Februari & 299000000 & 1.036789 \\
\hline & Maret & 315100000 & 5.109489 \\
\hline & April & 283900000 & -10.9898 \\
\hline & Mei & 235500000 & -20.552 \\
\hline & Juni & 281300000 & 16.28155 \\
\hline
\end{tabular}

Sumber: Data BPS diolah, 2020

\subsection{Nilai Ekspor Pertanian Indonesia}

Berdasarkan data tabel 3 nilai ekspor pertanian Indonesia cenderung berfluktuatif dari bulan ke bulan, dilihat dari perubahan persentase perubahan nilai ekspor perbulan tanpa pandemi COVID-19 pun, nilai ekspor pertanian sering mendapatkan nilai minus, faktor yang menyebabkan hal tersebut terjadi di bulan-bulan sebelum pandemi adalah perubahan iklim yang sangat drastis, hal yang sama diungkapkan oleh Sudarma (2018) yaitu perubahan iklim merupakan hal yang tidak dapat dihindari akibat pemanasan global yang berdampak luas terhadap berbagai sendi kehidupan. Perubahan pola curah hujan, peningkatan frekuensi kejadian iklim ekstrem, serta kenaikan suhu udara dan permukaan air laut merupakan dampak serius dari perubahan iklim yang berpengaruh terhadap sektor pertanian. Untuk Indonesia ancaman akan perubahan iklim akan memberikan dampak yang serius terhadap pencapain target pembangunan berkelanjutan. Sejalan dengan data di atas, maka penyebab utama berkurangnya nilai ekspor pertanian Indonesia disebabkan oleh volume ekspor pertanian yang menurun, volume eskpor yang menurun disebabkan oleh produksi pertanian yang menurun akibat perubahan iklim.

\section{Simpulan}

Penelitian ini menggunakan data bulanan dari bulan Mei tahun 2018 sampai bulan Juni tahun 2020. Berdasarkan hasil analisis data tersebut variabel yang mempengaruhi secara signifikan nilai ekspor pertanian Indonesia menggunakan acuan uji-t adalah variabel volume ekspor Indonesia (LNVEXP) dengan nilai variabel sebesar positif 0,686481 dan variabel volume ekspor pertanian Indonesia (LNVEXPP) dengan nilai variabel sebesar positif 0.542190 , sedangkan variabel lain yaitu pendapatan domestik bruto nasional (LNPDBN), kurs nilai tukar rupiah terhadap dolar Amerika Seriakt (LNEXCRT), dan variabel dummy COVID-19 tidak berpengaruh nyata berdasarkan uji-t, namun berpengaruh nyata apabila di uji bersama-sama menggunkan uji $\mathrm{F}$.

Nilai ekspor pertanian Indonesia sangat berfluktuatif dari bulan ke bulan, sebelum adanya pandemi COVID-19 nilai ekspor pertanian Indonesia sudah sering mengalami naik turun, hal utama yang menyebabkan kondisi tersebut terjadi adalah perubahan iklim yang drastis. Dilihat dari nilai variabel dummy COVID-19 yang bernilai negatif 0,01687 dan tidak signifikan menunjukkan bahwa apabila pandemi ini berlangsung dalam jangka panjang, diperkirakan akan menurunkan nilai ekspor pertanian Indonesia dan mungkin akan menghasilkan pengaruh nyata untuk uji-t. Perlu penelitian lebih lanjut untuk mengetahui dampak dari COVID-19 terhadap pertumbuhan nilai ekspor pertanian Indonesia apabila pandemi ini berlangsung dalam jangka panjang.

\section{Pustaka}

Badan Pusat Statistik. 2018. Buletin Statistik Perdagangan Luar Negeri Ekspor Menurut HS 2018.

BPS RI, 2018. 2019. Buletin Statistik Perdagangan Luar Negeri Ekspor Menurut HS 2019.

BPS RI, 2019.2020. Analisis Komoditas Ekspor, 2012-2019, Sektor Pertanian, Industri, dan Pertambangan. Jakarta,

BPS RI. 2020. Buletin Statistik Perdagangan Luar Negeri Ekspor Menurut HS 2020. BPS RI, 2020.

Fikriah. Arie Prawira. 2016. Analisis Pengaruh Produk Domestik Bruto, Nilai Tukar, dan Sosial Politik Terhadap Net Capital Inflow Indonesia. Jurnal Ekonomi Dan Kebijakan Publik. Volume 3 Nomor 1, Mei 2016.

Gujarati D. 2006. Essentials of Econometrics Third Edition. United States Military Academy, West Point (US): McGraw-Hill International Edition.

Ghozali, Imam. 2011. Aplikasi Analisis Multivariate Dengan Program SPSS Semarang, Badan Penerbit Universitas Diponegoro.

Kementerian Perencanaan Pembangunan Nasional Republik Indonesia/Badan Perencanaan Pembangunan Nasional. 2009. Penyebab Dan Dampak Krisis Keuangan Global. Jakarta, BAPPENAS RI.

Lestari, Dina Ayu., Rahmanta, Tavi Supriana. 2018. Factors Affecting Clove Exports in North Sumatera Province. International Journal of Progressive Sciences and Technologies (IJPSAT), Vol. 8 No. 2 May 2018.

Maisyarah, Siti. 2019. Pengaruh Nilai Tukar, Volume Ekspor, Dan Bea Keluar Herhadap Harga Ekspor Pinang (Studi Kasus Pada Perusahaan Eksportir CV. Mulia Karya). Tesis, http://repository.uinsu.ac.id/5984/1/TESIS\%20SITI\%20MAISYARAH.p df, diakses 07 Oktober 2020.

Maulana, Achmad Subchiandi, Rita Nurmalina, Suharno. 2016. The Analysis of Affecting Factors to the Export of Rattan Furniture Indonesia in the International Market. International Journal of Science and Research (IJSR) Volume 5 Issue 10, October 2016.

Sudarma, I Made, Abd. Rahman As-syakur. 2018. Dampak Perubahan Iklim Terhadap Sektor Pertanian Di Bali. Jurnal Sosial-Ekonomi Pertanian Dan Agribisnis (SOCA) Volume 12 No.1, Desember 2018.

Sugiyono. 2016. Metode Penelitian Kuantitatif, Kualitatif dan $R \& D$. Bandung, Alfabeta.

World Health Organization. 2020. Pertanyaan Dan Jawaban Mengenai Corona Virus. https://www.who.int/indonesia/news/novel-coronavirus/qa-forpublic. Diakses 01 Agustus 2020.

Yusdja, Yusmichad, Haryono Soeparno. 2011. Dampak Krisis Ekonomi Terhadap Pertanian Di Indonesia. Bogor, IPB Press. 